\title{
PROBLEMATIKA PEMBELAJARAN SKI DI MADRASAH TSANAWIYAH YAPI PAKEM
}

\author{
${ }^{1}$ Muhtar Luthfie Al Anshory, ${ }^{2}$ Marhumah, ${ }^{3}$ Suyadi \\ 1,2,3 Universitas Islam Negeri Sunan Kalijaga Yogyakarta \\ ${ }^{1}$ Email: muhtarluthfiealanshory@gmail.com \\ 2Email:marhumah@uin-suka.ac.id \\ Enmail:suyadi@uin-suka.ac.id
}

\begin{abstract}
Abstrak: Tujuan penelitian ini adalah untuk mengetahui problematika pembelajaran SKI di Madrasah Tsanawiyah YAPI Pakem Kabupaten Sleman. Jenis penelitian yang akan kami digunakan dalam penelitian ini adalah deskriptif kualitatif yang menekankan pada penggunaan data lapangan (alamiah). Data yang bersumber dari tatanan realitas yang dilakukan langsung oleh peneliti dalam situasi apa adanya. Penelitian deskriptif kualitatif berusaha mendeskripsikan seluruh gejala atau keadaan yang ada, yaitu keadaan gejala menurut apa adanya pada saat penelitian dilakukan.Hasil penelitian menunjukkan bahwa ketika dilakukan penelitian dengan menggunakan metode pendekatan kualitatif dan teknik pengumpulan data dengan observasi, wawancara, dan dokumentasi dilapangan tentang pembelajaran Sejarah Kebudayaan Islam di MTs YAPI Pakem Kabupaten Sleman mengalami beberapa kendala. Diantara kendala yang dialami dalam pembelajaran SKI adalah; pertama, adanya latar belakang peserta didik yang berbeda-beda. Kedua, latar belakang pendidikan guru yang tidak berkompeten. Ketiga, kurangnya sarana dan prasaranya dalam menunjang proses belajar mengajar SKI. Keempat, keterbatasan waktu dalam proses pembelajaran SKI di kelas.
\end{abstract}

Kata kunci: Pembelajaran, Problem SKI, SKI di Madrasah.

Title: Problematics Ski Learningin Madrasah Tsanawiyah Yapi Pakem

\begin{abstract}
The purpose of this study was to determine the learning problems of SKI in Madrasah Tsanawiyah YAPI Pakem. This type of research is descriptive qualitative that emphasizes the use of field data (natural). Data sourced from the order of reality is carried out directly by researchers in the situation it is. Qualitative descriptive research seeks to describe all the symptoms or conditions that exist, namely the state of symptoms according to what they are at the time the study was conducted. The resull of this reseaarch is in reality, when conducted research using a qualitative approach and data collection techniques with observation, interviews, and documentation in the field of learning the history of Islamic Culture in MTs YAPI Pakem Sleman Regency experienced several obstacles. Among the obstacles experienced in SKI learning are; First, there are different backgrounds of students. Second, the educational background of teachers who are not competent. Third, the lack of facilities and infrastructure in supporting the SKI teaching and learning process. Fourth, limited time in the SKI learning process in class.
\end{abstract}

Keywords: Learning, SKI Problems, SKI in Madrasah. 


\section{PENDAHULUAN}

Sejarah merupakan suatu kajian yang di dalamnya membahas tentang kejadian masa lampau yang dapat diambil hikmah dan kemudian dapat diterapkan dalam menjalani kehidupan yang akan datang, karena ketika kita mendalami ilmu sejarah pasti kita akan di suguhi berbagai peristiwa dan kejadian yang tidak jauh berbeda dengan kehidupan kita. Sedangkan sarana yang paling dominan untuk mencapai pengetahuan tersebut adalah dengan proses pendidikan. Menyadari hal tersebut, diberbagai lembaga pendidikan Islam yang ada hingga sekarang, bidang kajian sejarah kebudayaan Islam merupakan suatu bidang kajian yang cukup signifikan untuk dipelajari. Mempelajari sejarah kebudayaan Islam bertujuan untuk mengetahui berbagai masalah kehidupan umat manusia yang berkaitan dengan hukum Islam. Selain itu, dengan mempelajari Sejarah Kebudayaan Islam kita juga dapat memahami berbagai masalah kehidupan umat Islam, yang disertai dengan maju mundurnya kebudayan Islam itu sendiri. Kebudayaan atau peradaban yang dipengaruhi oleh nilai-nilai ajaran Islam disebut kebudayaan atau peradaban.

Kebudayaan tidak bertentangan dengan Islam karena cukup banyak ayat Al-Qur'an dan hadits yang mendorong manusia untuk belajar dan menggunakan akalnya melahirkan sesuatu yang bermanfaat untuk kehidupan masyarakat. Ini berarti Islam membenarkan penalaran akal pikiran dan mendorong semangat intelektualisme. ${ }^{1}$

Menurut Koentjaraningrat, kebudayaan paling tidak mempunyai tiga wujud diantaranya; Pertama, Wujud Ideal, yaitu wujud kebudayaan sebagai suatu kompleks ide-ide, gagasan, nilainilai, norma-norma, peraturan-peraturan dan lain-lain. Kedua, Wujud Kelakuan, yaitu wujud kebudayaan sebagai suatu kompleks aktivitas kelakuan berpola dari manusia dalam masyarakat. Ketiga, Wujud Benda, yaitu wujud kebudayaan sebagai benda-benda hasil karya. Sedangkan istilah peradaban biasanya dipakai untuk bagian-bagian dan unsur-unsur dari kebudayaan yang halus dan indah. ${ }^{2}$

Sedangkan kata Islam merupakan turunan dari kata assalamu, assalamatu yang berarti bersih dan selamat dari kecacatan lahir dan batin. Dan Islam dapat pula diartikan suci, bersih tanpa cacat. Islam adalah agama yang mengajarkan pada pemeluknya, untuk menyebarkan benih perdamaian, keamanan, dan keselamatan untuk diri sendiri, sesama manusia (muslim dan non muslim), dan kepada lingkungan sekitarnya (rabmatan lil 'alamin). Dari penegasan tersebut dapat dipahami bahwa Islam adalah agama yang diturunkan Allah kepada manusia melalui Rasul-Nya yang berisi hukum-hukum yang mengatur suatu hubungan segitiga yaitu hubungan antara manusia dengan Allah SWT (hablum min Allah), hubungan manusia dengan

\footnotetext{
${ }^{1}$ Rois Mahfud. Al-Islam Pendidikan Agama Islam, (Jakarta: Erlangga, 2011), h.185-186

2 Badri Yatim, Sejarah Peradaban Islam, (Jakarta: Grafindo Persada, 1997), h. 25
} 
sesama manusia (hablum min Annas), dan hubungan manusia dengan lingkungan alam semesta. ${ }^{3}$

Berdasarkan pengertian di atas, dapat dirumuskan tentang pengertian sejarah kebudayaan Islam, yaitu catatan peristiwa tentang pertumbuhan dan perkembangan pendidikan Islam sejak lahirnya sampai sekarang ini, serta suatu cabang ilmu pengetahuan yang berhubungan dengan pertumbuhan dan perkembangan Islam, baik dari segi gagasan atau ide-ide, konsep, lembaga maupun operasionalisasi sejak zaman Nabi Muhammad SAW hingga saat ini. ${ }^{4}$

Ir. Soekarno pernah berpesan untuk Jangan Sekali-kali Melupakan Sejarah (JASMERAH) ${ }^{5}$. Pesan tersebut menganjurkan kepada kita sebagai generasi muda harus tetap menjaga keutuhan nilai-nilai sejarah nenek moyang. Dengan begitu secara substansial mata pelajaran sejarah khususnya Sejarah Kebudayaan Islam memiliki kontribusi dalam memberikan motivasi kepada peserta didik untuk mengenal, memahami, menghayati Sejarah Kebudayaan Islam, yang mengandung nilai-nilai kearifan yang dapat digunakan untuk melatih kecerdasan, membentuk sikap, watak, dan kepribadian peserta didik.

Berbagai problematika yang mendasar dalam pembelajaran Sejarah Kebudayaan Islam di Madrasah MTs Yapi Pakem Kabupaten Sleman, beberapa diantaranya peserta didik dalam pembelajaran SKI terasa membosankan, banyak menghafal tahun, nama tokoh, nama tempat, nama asing, serta kejadian-kejadian runtut.

Dalam pembelajaran ada beberapa hal yang harus dilakukan oleh guru, mulai dari persiapan, pelaksanaan, hingga proses setelah pembelajaran. Namun kenyataan yang terjadi di lapangan menunjukkan adanya kesulitan yang dihadapi oleh para guru, terutama guru Sejarah Kebudayaan Islam MTs YAPI Pakem Kabupaten Sleman, karena siswanya sendiri merasa kesulitan untuk menerima pelajaran tersebut yang harus menghafalkan berbagai peristiwa dan tahun yang mestinya penting untuk diketahui oleh siswa, selain itu siswa menganggap mata pelajaran Sejarah Kebudayaan Islam merupakan pelajaran yang membosankan. Fakta lain juga menunjukkan, sering bergantinya kurikulum merupakan masalah yang harus dihadapi oleh guru dalam melakukan pembelajaran.

Berdasarkan uraian tersebut, maka penyusunan materi pelajaran Sejarah Kebudayaan Islam dapat dikembangkan menjadi beberapa komponen yang bertujuan untuk; Pertama, Meningkatkan pengenalan dan kemampuan mengambil ibrah terhadap peristiwa penting sejarah kebudayaan Islam, mulai dari perkembangan masyarakat Islam pada masa Nabi Muhammad SAW dan para khulafaurrasyidin, Bani Umaiyah, Abbasiyah, Al-Ayyubiyah

\footnotetext{
${ }^{3}$ Ibid., h. 3-4

${ }^{4}$ Hasbullah, Sejarah Pendidikan Islam Di Indonesia Lintasan Sejarah Pertumbuban dan Perkembangan, (Jakarta:PT Raja Grafindo, 2001), h. 8-9

${ }^{5}$ Moh. Ni'am Esha, Percikan Filsafat Sejarah Dan Kebudayaan Islam, (Malang: UIN Maliki Pers, 2001), h. 9. 78
} 
sampai dengan perkembangan Islam di Indonesia. Kedua, Mengapresiasi fakta dan makna peristiwa bersejarah dan mengaitkannya dengan fenomena kehidupan sosial, budaya, politik, pemerintahan, ekonomi, iptek, bahasa dan seni. ketiga, Meneladani nilai-nilai dan tokoh-tokoh yang berprestasi dalam peristiwa bersejarah.

Pembelajaran sejarah (termasuk SKI) dianggap tidak lebih dari rangkaian angka tahun dan urutan peristiwa yang harus diingat kemudian diungkapkan kembali pada saat menjawab soal ujian. Metode yang digunakan oleh guru masih monoton. Sejarah hanya disampaikan dengan ceramah, padahal materi sejarah Islam sudah diperoleh siswa sejak jenjang pendidikan tingkat Sekolah Dasar dan dari berbagai informasi. Melihat berbagai masalah yang muncul terkait dengan tuntutan dunia pendidikan, kesulitan siswa dalam belajar dan cakupan sejarah kebudayaan Islam yang luas, maka guru harus dapat memberikan tawaran untuk mengatasi kesulitan belajar siswa pada mata pelajaran sejarah kebudayaan Islam (SKI). Berdasarkan uraian terebut, maka penulis mencoba untuk melakukan mini risert tentang problematika pembelajaran SKI di Madrasah Tsanawiyah YAPI Pakem Kabupaten Sleman. Penulis akan mencoba mencari permasalahan bagai mana pembelajaran serta problematika pembelajaran SKI di madrasah tersebut.

\section{METODE PENELITIAN}

Jenis penelitian yang akan kami digunakan dalam penelitian ini adalah deskriptif kualitatif yang menekankan pada penggunaan data lapangan (alamiah). Data yang bersumber dari tatanan realitas yang dilakukan langsung oleh peneliti dalam situasi apa adanya. Penelitian deskriptif kualitatif berusaha mendeskripsikan seluruh gejala atau keadaan yang ada, yaitu keadaan gejala menurut apa adanya pada saat penelitian dilakukan'. Model penelitian deskriptif kualitatif ini juga mencerminkan situasi yang sebenarnya tanpa menambahnambahkan dan rekayasa pada variabel. Model penelitian ini adalah model yang mendapatkan data dengan cara sesuai fakta dan apa adanya dimana penelitian deskriptif kualitatif lebih memfokuskan pada hasil dan maknanya.

Pengumpulan data dilakukan dengan beberapa teknik agar tingkat validitas dan reliabilitas penelitian dapat dipertanggungjawabkan secara akademis. Jenis-jenis data yang diperoleh dari penelitian kualitatif antara lain berupa catatan lapangan, rekaman wawancara, foto dan lain-lain. Adapun teknik pengumpulan data dilakukan dengan teknik wawancara mendalam dan wawancara bebas, observasi atau pengamatan, dan dokumentasi. Ketiga teknik tersebut digunakan secara terpadu, baik dalam situasi yang sama atau berbeda-beda.

Dalam menganalisis data, peneliti memakai teknik penelitian deskriptif kualitatif, metode ini digunakan untuk menganalisa dan mengintepretasikan data yang berupa fakta-

\footnotetext{
${ }^{6}$ Sukardi, Metodologi Penelitian Pendidikan Kompetensi dan Praktiknya, (Jakarta: Bumi Aksara, 2008), h. 157
} 
fakta dari hasil penelitian yang tidak berwujud angka. ${ }^{7}$ Tahapan awal dalam penelitian deskriptif kualitatif adalah tahap memasuki lapangan, dengan grandtour dan monitor question. Analisis datanya dengan analisis domain. Tahap kedua adalah menentukan focus teknik pengumpulan data dengan monitor question. Analisis datanya dengan analisis taxonomi. Selanjutnya pada tahap seleksi, pertanyaan yang digunakan adalah pertanyaan structural, Analisis datanya dengan analisis komponencial, setelah itu dilanjutkan analisis tema. Jadi analisis data kualitatif dilakukan secara interaktif melalui proses data reduction, data display dan verifikasi.

\section{HASIL PENELITIAN DAN PEMBAHASAN}

\section{Proses Pembelajaran Sejarah Kebudayaan Islam di MTs Yapi Pakem}

Mata pelajaran SKI Madrasah Tsanawiyah Yapi Pakem meliputi: sejarah Pra Islam, Nabi Muhammad, Khulafaur Rasyidin, dinasti Umayah, Abbasiyah dan al-Ayubiyah, masuknya Islam di Nusantara, dan tradisi Islam Nusantara. Hal lain yang sangat mendasar adalah terletak pada kemampuan menggali nilai, makna, aksioma, ibrah/hikmah, dalil dan teori dari fakta sejarah yang ada. Oleh karena itu dalam tema-tema tertentu indikator keberhasitan belajar akan sampai pada capaian ranah afektif. Jadi SKI tidak saja merupakan transfer of knowledge, tetapi juga merupakan pendidikan nilai (value education). Dari hasil observasi dan wawancara yang Penulis lakukan di MTs YAPI Pakem, beberapa hal yang dilakukan guru SKI dalam proses pembelajaran, sebagai berikut:

1. Membuat rencana pelaksanaan pelajaran

Dalam PP RI No. 19 Tahun 2005 tentang Standar Pendidikan Nasional Pasal 20 dinyatakan bahwa: Perencanaan proses pembelajaran meliputi silabus dan rencana pelaksanaan pembelajaran yang memuat sekurang kurangnya tujuan pembelajaran, materi ajar, metode pengajaran, sumber belajar, dan penilaian hasil belajar, yang mana dalam pelaksanaannya dibagi ke dalam 3 tahapan yaitu kegiatan awal, kegiatan inti, dan kegiatan akhir.

a. Kegiatan awal

Pertama membuka pelajaran. langkah pertama guru masuk dan salah satu siswa yang bertindak sebagai ketua kelas memimpin untuk berdo'a, setelah berdo'a dilanjutkan memberi salam kepada guru. Kedua persiapan pembelajaran. Dalam kegiatan ini guru mengajak peserta didik untuk menyiapkan segala peralatan pembelajaran seperti buku paket, buku tulis, dan lain sebagainya.

${ }^{7}$ Sutrisno Hadi, Metodologi Research 1, (Yogyakarta : Psikologi UGM Press, 1987), h.4 
b. Kegiatan inti

Dalam hal ini guru memulai dengan melakukan pengulasan materi yang sebelumnya. Kemudian guru menjelaskan materi yang akan dibahas. Adapun metode atau media yang digunakan kurang begitu mendapatkan perhatian, jadi bisa dikatakan bahwa metode yang digunakan hanya ceramah dan tanya jawab. Dalam menjelaskan materi guru tidak hanya berpedoman pada buku paket yang telah ada tetapi juga disertai dengan gambaran berupa cerita atau contoh nyata di kehidupan sehari-hari yang berkaitan dengan materi yang disampaikan. Selain itu dalam penyampaian materi belajar guru menyelipkan guyonan agar peserta didik tidak bosan saat kegiatan belajar mengajar sedang berlangsung.

c. Kegiatan akhir

Guru memberikan waktu kepada peserta didik untuk melaksanakan tanya jawab, guru memberikan tugas mengenai materi yang disampaikan, guru dan peserta didik bersama-sama membahas tugas yang diberikan, guru beserta peserta didik membuat kesimpulan mengenai materi yang disampaikan pada sat itu, dan kemudian guru menutup kegiatan belajar mengajar

2. Metode dan Media Pembelajaran SKI di MTs YAPI Pakem

Metode pembelajaran yang sering digunakan oleh guru SKI MTs YAPI Pakem adalah dengan menggunakan metode ceramah, tanya jawab, diskusi, kerja kelompok, dan Active Knowledge Sharing (Aktif Berbagi Pengetahuan). Diharapkan metode tersebut dapat memberikan pengetahuan kepada peserta didik untuk memahami dan mengambil ibrah dalam mempelajari Sejarah Kebudayaan Islam. Penggunaan metode tersebut dilakukan oleh guru tidak lain dengan mempertimbangkan berbagai hal salah satunya waktu, serta karakter peserta didik yang ada di MTs YAPI Pakem.

Media pembelajaran yang digunakan guru SKI yaitu buku paket, buku sumber primer, white board, LCD, HP, dan wifi display dogle. Secara keseluruhan dari media yang sering di gunakan oleh guru SKI MTs YAPI Pakem yaitu dengan menggunakan media white board dan LCD karena media tersebut yang diminati oleh peserta didik dalam pembelajaran SKI, meskipun pelaksanaannya penggunaan LCD bisa berupa menonton film yang berhubungan dengan pelajaran SKI dan slide share materi SKI. Seiring perkembangan teknologi yang begitu canggih, guru SKI dalam menggunakan media pembelajaran SKI tidak lagi menggunakan laptop melainkan menggunakan HP yang terhubung dengan wifi dislay dogle, sehingga mempermudah guru dalam membawa media pembelajaran SKI kedalam kelas. 
3. Membuat evaluasi pembelajaran

Penilaian merupakan rangkaian kegiatan untuk memperoleh, menganalisis, dan menafsirkan data tentang proses dan hasil belajar peserta didik yang dilakukan secara sistematis dan berkesinambungan, bersifat informatif dan bermakna dalam pengambilan keputusan. Oleh karena itu, konsep penilaian pembelajaran disebut dengan “Classroom Assessment". Sementara itu penilaian atas hasil belajar siswa menyangkut pemenuhan pemahaman dan kompetensi yang diharapkan sebagaimana dirumuskan dalam standar kompetensi dan kompetensi dasar yang indikatornya bisa di lihat dari tujuan pembelajaran. Hasil pembelajaran yang di evaluasi bisa pada ranah pengetahuan, sikap dan perilaku. ${ }^{8}$

Evaluasi yang dilakukan oleh guru dalam pembelajaran SKI dengan menggunakan teknik tes lisan dan tertulis, observasi, penugasan terstruktur dan tidak terstruktur, serta portofoli. Berikut tabel klasifikasi evaluasi pembelajaran SKI di MTs YAPI Pakem.

\begin{tabular}{|c|c|c|}
\hline Teknik & Jenis & Intrument \\
\hline \multirow[t]{4}{*}{ Tes } & \multirow[t]{2}{*}{ Tulis } & $\begin{array}{l}\text { Tes Objektif: } \\
\text { Tes Pilihan Ganda } \\
\text { Benar-Salah } \\
\text { Menjodohkan, dll }\end{array}$ \\
\hline & & $\begin{array}{l}\text { Tes Uraian : } \\
\text { Uraian Objektif/Isian Singkat } \\
\text { Uraian/Essay }\end{array}$ \\
\hline & Lisan & Daftar Pertanyaan \\
\hline & Unjuk Kerja & $\begin{array}{l}\text { Tes Identifikasi } \\
\text { Tes Simulasi } \\
\text { Tes Uji Petik Kinerja }\end{array}$ \\
\hline \multirow[t]{2}{*}{ Observasi } & Langsung & Check List \\
\hline & Laporan Pribadi & Rating Scale \\
\hline \multirow{2}{*}{$\begin{array}{c}\text { Penugasan } \\
\text { terstruktur dan } \\
\text { tidak terstruktur }\end{array}$} & Individu & \multirow{2}{*}{$\begin{array}{l}\text { Pekerjaan Rumah } \\
\text { Proyek }\end{array}$} \\
\hline & Kelompok & \\
\hline Portofolio & Dokumentasi & Lembar Portofolio \\
\hline Evaluasi diri & Tulis & Quesioner \\
\hline
\end{tabular}

4. Kesan Siswa Terhadap Guru dan Mata Pelajaran SKI di MTs YAPI Pakem

Menurut sebagian besar siswa MTs YAPI Pakem, pelajaran SKI merupakan pelajaran yang menyenangkan sebab guru selalu terkesan humoris dalam menyampaikan materi. Sebagai contoh, guru selalu memberi unsur komedi dan reward di sela-sela menerangkan materi kepada siswa. Hal ini menjadikan semangat kepada siswa yang hampir surut akibat terlalu padatnya jadwal dan jenuhnya siswa seharian dalam belajar. Selain itu metode yang digunakan juga menjadikan siswa antusias untuk mengikuti pembelajaran SKI. Hal ini terbukti dengan jarangnya siswa yang absen pada jam pelajaran

8 M. Hanafi. Pembelajaran Sejarah Kebudayaan Islam. (Jakarta : Dirjen Pendidikan Agama Islam Departemen Agama RI) 2009 
SKI. Akan tetapi sedikit keluhan dari siswa, selain gurunya disiplin dan tegas dalam menerangkan juga terlalu sulit dalam menghafal nama-nama tokoh, waktu dan tempat kejadian. Meskipun guru sudah menggunakan berbagai metode dari mulai bernyanyi, bermain peran, memberikan gambaran kejadian masa kini dan lain sebagainya tetap saja siswa masih mengalami kesulitan dalam memahami SKI.

\section{Problematika Pembelajaran Sejarah Kebudayaan Islam di MTs YAPI Pakem}

Berdasarkan hasil observasi dan wawancara, kenyataannya dalam melaksanakan kegiatan proses belajar mengajar pada mata pelajaran SKI di lingkungan MTs YAPI pakem, penulis menemukan beberapa problem yang secara langsung atau tidak langsung dapat menghambat proses pelaksanaan pembelajaran SKI. Problem itu tidak hanya ada pada pendidik maupun peserta didik sebagai pelaku dalam proses pendidikan akan tetapi juga terdapat pada faktor lingkungan internal dan eksternal, juga pada manajemen, sarana dan prasarana. Problematika pelaksanaan pembelajaran SKI yang ada di MTs YAPI Pakem adalah:

1. Latar belakang Perserta Didik

Dalam hal ini mayoritas peserta didik yang ada di lingkungan MTs YAPI Pakem mempunyai background pendidikan Sekolah Dasar, yang sama sekali belum pernah diajarkan tentang Sejarah Kebudayaan Islam, hanya sebatas kisah para Nabi dan Rosul tidak lebih spesifik membahas tentang SKI. Selain itu pula peserta didik MTs YAPI Pakem mengeyam pendidikan di MTs bukan merupakan pilihan utama melainkan karena keterpaksaan, dari pada tidak sekolah lebih baik melanjutkan tetapi di Madrasah. Selain itu, kurangnya tingkat kecerdasan siswa antara satu dengan yang lainnya dalam memahami suatu pelajaran. Permasalahan keluarga yang dialami oleh peserta didik MTs YAPI Pakem juga ikut memicu kurangnya minat anak untuk menuntut ilmu. Maka dari berbagai masalah tersebut menimbulkan kendala peserta didik dalam memahami dan menjalankan proses belajar Sejarah Kebudayaan Islam.

2. Tenaga Profesional Guru SKI tidak Kompeten

Tenaga Pengajar merupakan salah satu faktor pendidikan yang amat penting, ukuran Tenaga Pengajar yang baik adalah kompetensi dan profesional. Tenaga Pengajar yang kompeten akan menuju kepada Pendidikan profesional dalam melaksanakan proses belajar mengajar. Dalam pelaksanaannya tenaga pengajar SKI di MTs YAPI pakem tidak sesuai dengan latar belakang pendidikannya sehingga sangat mempengaruhi sekali dalam proses belajar mengajar di kelas. Selain itu guru SKI di MTs YAPI Pakem masih berstatus guru Non PNS (Honorer) dengan gaji yang tidak mencukupi, sehingga membawa dampak kurangnya tanggung jawab dalam mengajar. Serta kurangnya kerjasama antara orang tua siswa dan guru dalam menjalin hubungan kerja sama dalam membimbing anaknya untuk belajar Sejarah Kebudayaan Islam. Hal ini dikarenakan 
kurangnya SDM yang dibuktikan dengan pendidikan orang tua siswa yang rata-rata hanya sampai sekolah menengah pertama dan bahkan ada juga yang tidak pernah mengenyam pendidikan sama sekali. Karena faktor tersebut ketika siswa berada di lingkungan keluarga jarang sekali orang tua menyuruh anaknya untuk belajar walau hanya sebatas membaca buku pelajaran.

3. Fasilitas dan Sarana prasarana

Sarana pendidikan adalah suatu sarana dan perlengkapan yang menunjang proses belajar mengajar. Adapun yang dimaksud dengan prasarana pendidikan adalah fasilitas yang secara tidak langsung menunjang jalanya proses pendidikan atau pengajaran di dalam kelas. Adapun sarana dan prasarana yang dimiliki MTs YAPI Pakem dalam menunjang proses belajar mengajar SKI kurang begitu memadai, salah satunya yaitu masih adanya LCD yang rusak dan belum diganti, white board yang sudah usang, minimnya buku referensi Sejarah Kebudayaan Islam di perpustakaan, serta kurangnya pendingin ruangan yang menjadikan siswa merasa kepanasan saat proses belajar mengajar di kelas. Diharapkan dengan adanya sarana dan prasarana yang memadai dan sesuai harapan dapat menciptakan sekolah yang menyenangkan bagi pendidik dan peserta didik. Untuk mewujudkan sarana dan prasarana tersebut diperlukan dana yang memadai, sedangkan untuk meremajakan fasilitas tersebut MTs YAPI Pakem ter kendala dana yang kurang memadai sehingga mau tidak mau guru hanya bisa memanfaatkan fasilitas yang ada dalam proses belajar mengajar.

4. Waktu atau Jam Pelajaran sangat singkat

Kendala lain yang dialami oleh guru SKI di MTs YAPI Pakem adalah minimnya jam pelajaran yang diberikan yaitu 2 jam pelajaran per minggu. Meskipun pembagian jam tersebut sudah menjadi aturan dari pemerintah, akan tetapi materi tentang Sejarah Kebudayaan Islam yang di ajarkan begitu banyak dan memang penting untuk disampaikan kepada peserta didik sehingga menuntut guru untuk pandai-pandainya memanfaatkan waktu. Hal ini yang menjadi kendala yang besar dalam penyampaian materi kepada siswa.

\section{SIMPULAN}

Pembelajaran Sejarah Kebudayaan Islam adalah proses perubahan cara berfikir siswa tentang berbagai kejadian masa lampau khususnya dalam perkembangan peradaban Islam untuk dapat diambil manfaatnya (ibrah) yang terkandung dalam setiap peristiwa sehingga dapat dijadikan pelajaran untuk menjalani hidup dimasa kini dan akan datang. Dari hasil observasi dan wawancara di MTs YAPI Pakem dalam pelaksanaan pembelajaran Sejarah Kebudayaan Islam dijumpai beberapa masalah dan kendala dalam menunjang proses belajar 
mengajar peserta didiknya diantaranya berupa latar belakang problematika yang dialami siswa, keprofesionalitasan Guru yang tidak sesuai dengan pendidikannya, sarana dan prasarana yang kurang begitu memadai, serta alokasi waktu yang diberikan dalam proses belajar mengajar di kelas terlalu singkat.

Dari kendala tersebut di atas kiranya penting untuk meningkatkan kualitas profesionalitas guru Sejarah Kebudayaan Islam dengan mengikuti berbagai kegiatan seperti KKG, bedah buku, diklat mata pelajaran SKI, maupun kegiatan lainnya yang menunjang dalam kegiatan belajar mengajar SKI. Selain itu pula sarana dan prasarana minimal dapat menunjang proses belajar mengajar di kelas. Dengan begitu meskipun latar belakang siswa yang berbeda-beda tetapi guru akan dengan mudah memberikan materi SKI dengan model atau metode yang lebih baik dan menarik, sehingga mapel SKI tidak lagi dipandang sebagai mapel yang sulit untuk dipelajari.

\section{DAFTAR PUSTAKA}

Biyanto, Teori Siklus Peradaban, Surabaya. LPAM. 2004

Depdiknas, Pelatihan Terintegrasi Berbasis Kompetensi Guru Pelajaran Bahasa Indonesia, "Metode Pembelajaran”. Jakarta. Media Press. 2002.

Esha, Moh. Ni'am, Percikan Filsafat Sejarah dan Kebudayaan Islam. Malang: UIN Maliki Pers. 2001.

Hadi, S. Metodologi Research 1, Yogyakarta. Psikologi UGM Press. 1987

Hanafi, M. Pembelajaran Sejarah Kebudayaan Islam. Jakarta. Direktorat Jenderal Pendidikan Islam Kementerian Agama RI. 2012.

Hanafi, M. Pembelajaran Sejarah Kebudayaan Islam. Jakarta. Dirjen Pendidikan Agama Islam Departemen Agama RI. 2009

Hasbullah, Sejarah Pendidikan Islam Di Indonesia Lintasan Sejarah Pertumbuban dan Perkembangan, Jakarta. PT Raja Grafindo. 2001.

Kusdiana, A. Sejarah \& Kebudayaan Islam Periode Pertengahan, Bandung. Pustaka Setia. 2013.

Mahfud, R. Al-Islam Pendidikan Agama Islam, Jakarta. Erlangga. 2011.

Peraturan Mentri Agama RI nomor 2 tahun 2008 Tentang Standar Kompetensi Lulusan dan Starndarisi Pendidikan Agama Islam dan Bahasa Arab di Madrasah Ibtidaiyah

Poebakwatja, S. dan Harahap. Ensiklopedia Pendidikan, Jakarta. Gunung Agung. 1982.

Rohman, A. S. Minat Siswa Dalam Mata Pelajaran Sejarah Kebudayaan Islam Di Kelas VIII H MTs N Ariyojeding Rejotangan Tulunggung Tabun Ajaran 2011/2012, (Tulungagung: Skripsi tidak diterbitkan, 2012. 
Jurnal Penelitian Keislaman Vol.16 No.1 (2020): 76-

Sukardi, Metodologi Penelitian Pendidikan Kompetensi dan Praktiknya, Jakarta. Bumi Aksara. 1987 Yatim, B. Sejarah Peradaban Islam, Jakarta. Grafindo Persada. 1997. 